\title{
Investigating the effect of emotional and social stimulants of store atmosphere and prices on the customers' satisfaction and loyalty
}

\author{
Seyyed Hamid Khodadad Hosseini ${ }^{\mathrm{a}^{*}}$, Alireza Mosayebi ${ }^{\mathrm{b}}$ and Jalal Khorram ${ }^{\mathrm{c}}$
}

\author{
${ }^{a}$ Associate Professor, Business Management, Faculty of Management \& Economics, Tarbiat Modarres University, Tehran, Iran \\ ${ }^{b}$ Msc in Business Management, Faculty of Management \& Economics, Tarbiat Moddares University, Tehran, Iran \\ ${ }^{c}$ PH.D student of HRM, Islamic Azad University_Isfahan Science \& Research Branch, Isfahan, Iran

\section{H R O N I L E A B S T R A T}

Article history:

Received January 22, 2013

Received in revised format

26 April 2013

Accepted 20 May 2013

Available online

May 282013

Keywords:

Emotional stimulants

Social stimulants

Store atmosphere

Price

Customers' satisfaction

Loyalty

\begin{abstract}
Nowadays, it is impossible for retailers to establish a competitive and successful store in the marketplace through making a distinction in the outer facades of their stores, altering the pricing system, and diversifying the products offered in the store, due to the intense competition emerged in retailing markets. This leads the retailing markets to a new concept of marketplace, which is called "teaser retailing". In this research, we first explain some related variables such as emotional and social stimulants, emotional-perceptual indicators, price of product, customer satisfaction, and customer loyalty. Then we investigate the impact of emotional and social stimulants and price of products on emotional-perceptual indicators as well as the relationship between emotional-perceptual indicators and customer satisfaction, and finally the relationship between customer satisfaction and his/her loyalty. The first hypothesis was associated with the effect of the store emotional stimulants on emotional-perceptual indicators and it was not confirmed. After investigation of the second hypothesis, it was cleared that the store social stimulants affects the buyer's emotional-perceptual indicators in purchasing point. On the other hand, the third hypothesis indicated that price of products affects the buyer's emotionalperceptual indicators in purchasing point. The fourth hypothesis indicated that emotionalperceptual indicators affect the customer satisfaction, and finally the fifth one indicated that the customer satisfaction leads to his/her loyalty.
\end{abstract}

\section{Introduction}

Nowadays, it is impossible for retailers to construct a competitive and successful store in the marketplace through making a distinction in the outer facades of their stores, altering the pricing system, and diversifying the products offered in the store, due to the intense competition emerged in retailing markets. This leads the retailing markets to a new concept of marketplace, which is called "teaser retailing" (Berman \& Evans, 2009). The new concept incorporates the things like retailing, entertainment, background music, and spending leisure time, and provides a pleasant and enjoyable place for today's customers in addition to offering products in the purchasing process. 
According to Babin and Attaway (2000), the environmental factors of store atmosphere influence the customers' experienced implicit feelings and, consequently, influence the purchase intention, consuming extent, perceived quality, satisfaction, and purchasing value. The desired store atmosphere normally increases the length of purchasing time, purchasing satisfaction, and previously planned returning to store in the next times. In other words, it leads to more customer loyalty (Shen \& Hsieh, 2011). Furthermore, during the last two decades, many studies have been accomplished concerning the effect of retailing price on the emotional and perceptual modes of customers, which generally indicate that the goods' prices and discounts positively influence the emotional and perceptual indicators of customers (Eggert \& Ulaga, 2002; Faullant et al., 2011; Kaltcheva \& Weitz, 2006).

Overall, performed researches have performed an investigation and confirmed the relationships between these variables, but the main challenge is to identify the direction and types of the relationships. Thus, the present study seeks to determine the type and direction of the relationships between background music, purchase intention, and duration of the customer retention in the store.In order to investigate the problem expressed in the previous section, first we review the related literature and investigate the variables of the conceptual model and their relationships in the form of the research hypotheses. These variables include the emotional and social stimulants of store atmosphere, price of the products, emotional-perceptual indicators of the customer, customer satisfaction, and customer loyalty.

\section{Literature}

\subsection{Emotional and social stimulants}

Although many studies have been conducted about stores' atmosphere and customer behavior, but it should be noted that they only investigated the impact of environmental factors (e.g., music playback, temperature, etc.) on the customer behavior separately (Shen \& Hsieh, 2011). Nevertheless, the purchase process is a perfect experience in which the specific environmental factors cannot be separated and their effect on the customer perception and behavior cannot be separately investigated. On the other hand, it can be said that the store atmosphere is not a laboratory environment where the real feelings and perceptions of the customer could be reflected by limiting and controlling some specific variables (ibid.).

\section{Table 1}

Classification of the variables existing in the store atmosphere

\begin{tabular}{|c|c|}
\hline Researcher & Classification \\
\hline Baker(1986) & $\begin{array}{l}\text { Classified the stimulants of store atmosphere in three categories: } \\
\text { 1. Environmental factors affecting the store atmosphere, which can be controlled by the vendor (such as temperature, music, } \\
\text { sound, light, etc.) } \\
\text { 2. Factors relating to the store design and decoration having aesthetic aspect like the goods arrangement, the store architecture, } \\
\text { etc. } \\
\text { 3. social factors referring to human issues and concerning the vendors and customers like the number of customers and vendors' } \\
\text { behavior. }\end{array}$ \\
\hline Bitzer(1992) & $\begin{array}{l}\text { Classified the physical factors of store atmosphere in three categories: } \\
\text { 1. The controllable circumstances of store like the music, natural sounds, temperature, light, smell, etc. } \\
\text { 2. The arrangement of equipment and ministerial furniture } \\
\text { 3. The signs and symbols used directly or indirectly to transfer some specific messages to customers. }\end{array}$ \\
\hline $\begin{array}{l}\text { Berman \& } \\
\text { Evans(2009) }\end{array}$ & $\begin{array}{l}\text { Suggested a new classification by modifying and completing the study of Bitzer (1992) including the external environment of the } \\
\text { store, internal atmosphere, arrangement of selling accessories, and visual factors of the purchase point and goods arrangement. }\end{array}$ \\
\hline $\begin{array}{l}\text { Turly \& } \\
\text { Milliman(2010) }\end{array}$ & $\begin{array}{l}\text { Developed a new classification using the classification of Berman and Evans and adding the human factor to it. They categorized } \\
58 \text { environmental factors in } 5 \text { categories like the following: } \\
\text { 1. External variables including the outsider tableau, entrance, showcase and architecture of the store, and environmental } \\
\text { atmosphere. } \\
\text { 2. Internal variables including the roof and floor, aroma, music, temperature, cleanness, and color composition of the walls. } \\
\text { 3. Variables relating to decoration and arrangement including the quality of space allocation to different works and services, } \\
\text { equipment arrangement, goods grouping, waiting room, instruments of waiting room. } \\
\text { 4. Variables of purchase point and store decoration including the goods packaging, purchase location, signs, symbols, and store } \\
\text { tableau, appearance of working place, appearance of price tableaus. } \\
\text { 5. human variables including the employees features, working clothes, customers plurality and density, customers features, } \\
\text { customers safety. }\end{array}$ \\
\hline
\end{tabular}


According to these studies, it is clear that the different researchers have suggested various classifications of variables influencing the stores' atmosphere and some of them are listed in the following Table 1. After investigating the previous studies and categorizations of the store stimulants, we provide a new one and categorize them into two categories of emotional and social stimulants. Emotional stimulants are of those stimulants, which influence five senses such as music, arrangement, aroma, etc. Social stimulants are human factors inside the store like how the store employees deal with the customers and with each other, wearing uniform, accessibility of the store managers, etc. In this study, a new classification of variables influencing the cognition and feelings of the customers is provided and the effects of this set of variables on the customers' feelings and perceptions and consequently on their satisfaction and loyalty will be investigated by applying a practical model.

Hypothesis 1: emotional stimulants of the store atmosphere affect the emotional-cognitive indicators of the customer in point of purchase.

Hypothesis 2: social stimulants of the store atmosphere affect the emotional-cognitive indicators of the customer in point of purchase.

\subsection{Price}

After a comprehensive study, Shirai (2009) concluded that the high or low price of the products is effective on the perceptions and feelings of the customer and consequently on his/her purchase intention. He stipulated that the high or low prices create various emotional states in the customer that appear on a spectrum from disinterest to excitement, which leads to more purchase or to avoid purchasing. Many studies can be found suggesting the effect of price on the customer perception and a comparison between price and the customer's expectation of product for fulfilling his/her need (e.g., Ladhari, 2010 , Lai et al., 2008; Richins, 1997; Westbrook \& Oliver, 1991).

Hypothesis 3: The appropriate price of goods affects the emotional-cognitive indicators of the customer.

\subsection{Emotional-cognitive indicators of the customer and satisfaction}

In order to have better understanding on how intra-store variables influence the customers' satisfaction and loyalty, first we should find out about different kinds of states and feelings that customer experience in the stores' atmosphere. The states that exist in the store atmosphere either naturally or virtually have a significant effect on the customer behavior (Faullant et al., 2011). The customer's feelings and modes are situational factors, which affect his/her propensity to purchase given the existing conditions of the place (Baker et al., 2002). Therefore, the emotional state of the customer mediates the relationship between the store atmosphere and the purchase behavior (Wirtz et al., 2000). In addition, many studies indicate that the customer excitement is positively associated with the perceived activity (Ladhari, 2007). In this regard, recent researches indicated that the customer objective and propensity act as a mediator variable (Kaltcheva \& Weitz, 2006). Baker et al. (2002) stated that various environmental variables have been studied separately specially music (Laros \& Steenkamp, 2004; Lai et al., 2009; Hui et al., 1997) and aroma (e.g., Faullant et al. ,2011), which mostly done subjectively in a virtual environment. Only few studies have been done in a real environment and among the real customers. Customer satisfaction is defined as a psychological state representing for internal feelings of the customer towards the previous purchasing experience and comparing his/her expectations with the purchase achievements (Wirtz et al., 2000). Many studies indicate that the various emotional states emerging in a person influences his/her satisfaction (Laros \& Steenkamp, 2004; Russel \& Barett fledman, 1999; Waston \& Clarck, 1992; Wirtz et al., 2000; Ladhari, 2007). In addition, Faullant et al. (2011) concluded from their study that the customer 
perception of the environmental factors affects his/her satisfaction with the environment and his/her activities in that environment such as purchasing.

Hypothesis 4: emotional-cognitive indicators of the customer affect his/her purchasing satisfaction.

\subsection{Loyalty}

Loyalty is defined as the customer tendency for repurchasing a product, which is previously purchased from a familiar place based on his/her experiences and satisfaction. Customer satisfaction is often considered as an important indicator of intention to repurchase (Lai et al., 2009). Furthermore, Eggert and Ulaga (2002) concluded that the customer satisfaction is associated with his/her loyalty. Cronin et al. (2000) also indicated that three variables of satisfaction, perceived value, and service quality affect the customer loyalty, which among them the customer satisfaction is of a great importance.

Hypothesis 5: Customer satisfaction affects his/her loyalty.

\section{Conceptual framework}

Conceptual model of the present study includes the predictor, outcome, mediator, and moderator variables (Fig. 1) which were explained in the previous section. Meanwhile, the relationships between these variables were investigated according to previous studies.

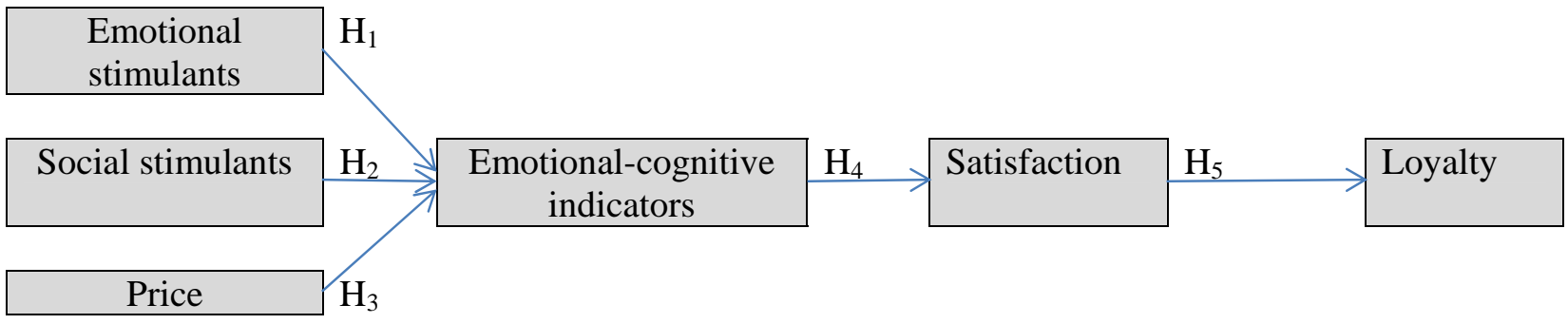

Fig. 1. The conceptual model

\section{Research method}

The present study is a survey research in terms of method and an applied-developmental research in terms of objective. Understudy population is the customers of Refah stores and the statistical sample was selected through the random sampling method and using the sampling formula for unlimited population where $\mathrm{d}=.06, \mathrm{z}=1.96, \mathrm{p}=0.5$.

Table 2

Research variables (The number of items and Cronbach's alpha)

\begin{tabular}{lcc}
\hline variable & Number of items & Reliability (alpha) \\
\hline Emotional Stimulant & 5 & .803 \\
Social Stimulants & 7 & .654 \\
Price & 3 & .641 \\
Perceptual-social Stimulant & 5 & .560 \\
Customer Satisfaction & 4 & .760 \\
Customer Loyalty & 3 & .890 \\
\hline Total & 27 & .789 \\
\hline
\end{tabular}

The sample size was about 120 given a reserve amount considered for uncompleted questionnaires. Data gathering instrument in this study is questionnaire including the customers' general information and 27 items in both the 5-point Likert-type scale and the yes-no scale. Cronbach's alpha was .83 and Split-half reliability was .80, which portend a reliable questionnaire. Validity was investigated using the content validity and the confirmatory factor analysis methods. Data was analyzed using the descriptive statistics and structural equation modeling (Lizrel v8.7) to test the main paths between 
variables. In the path analysis method, the path coefficients and t-values is calculated and based on its multiplication rule the direct and indirect effects of each independent variable on the dependent variable are determined. The variables of research model in terms of their items and Cronbach's alpha are provided in Table 2 .

\section{Findings}

This section presents the overall features of participants as well as it explains the statistical analyzes resulted from the path analysis approach to structural equation modeling. Fig. 2 shows personal characteristics of the participants. In this study, 70 people were male while 45 people were female. In terms of age, 20 participants aged 30 years or less, 65 people were between 30 to 40 years old and 30 people were older than 40 .
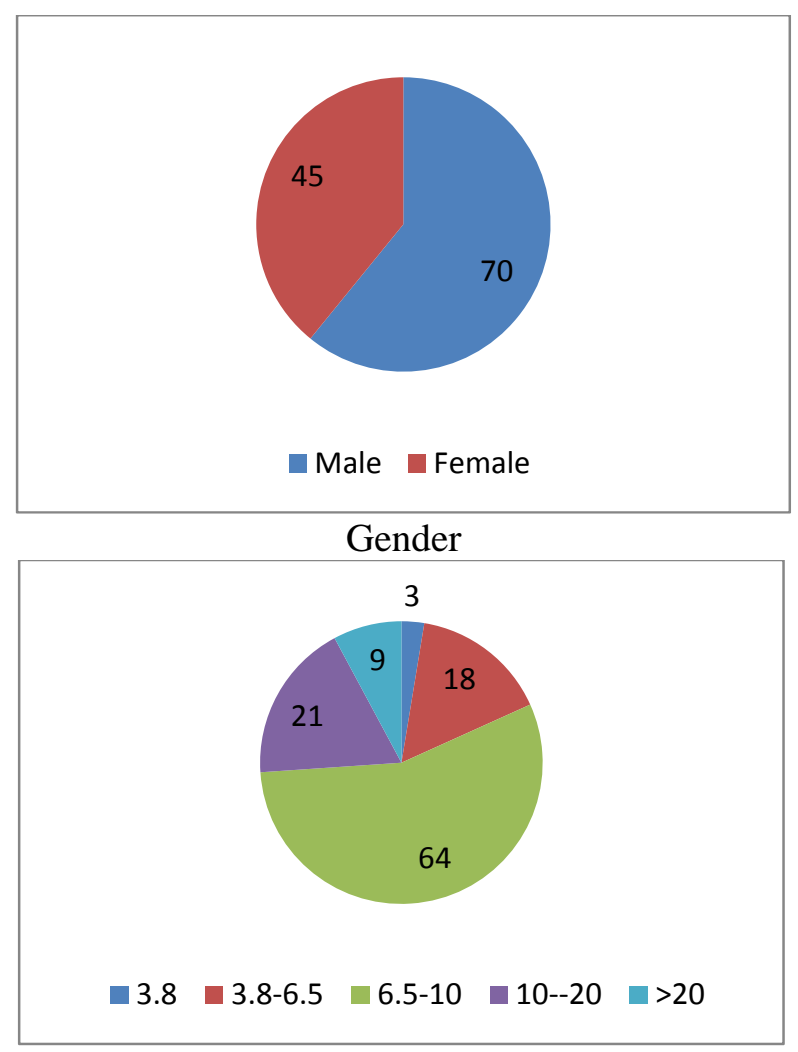

Average monthly wage (M Rials)

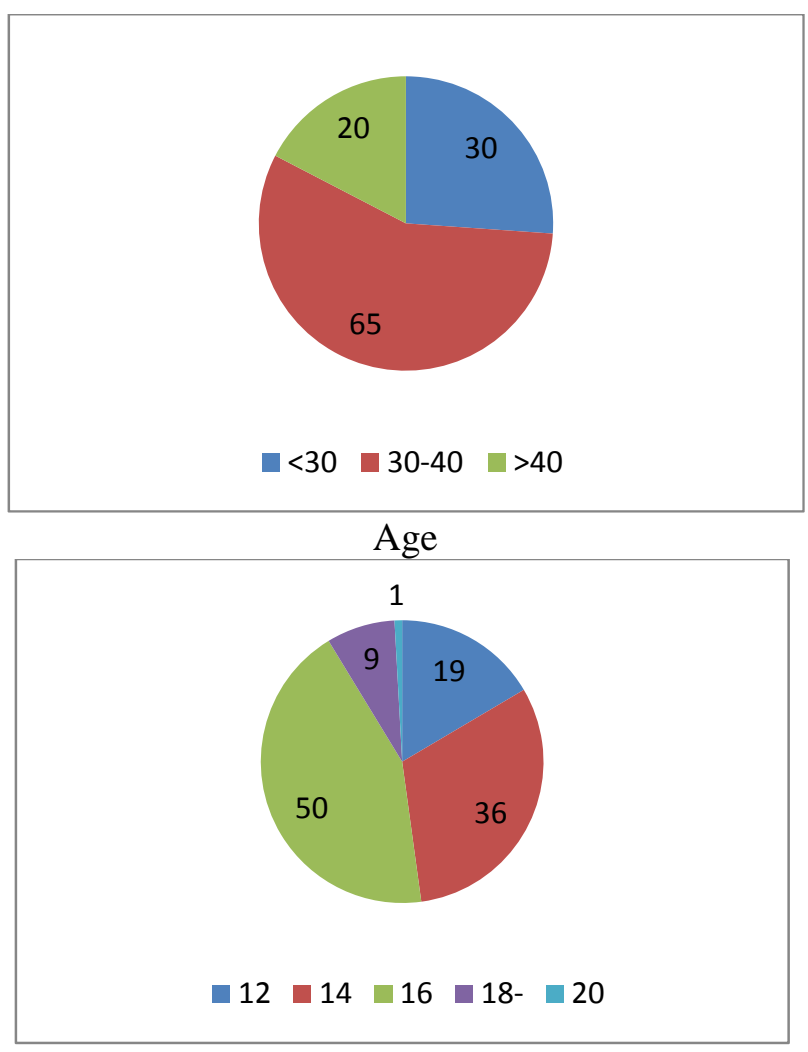

Years of educational background

Fig. 2. Personal characteristics of the participants



Fig. 3. Model estimation and the path coefficients between variables 


\subsection{Hypotheses testing via the path analysis approach}

\subsubsection{Evaluation of the path model using the structural equation modeling}

In this section, the structural equation modeling is conducted in order to test the causal relationships between emotional stimulants, social stimulants, price, perceptual-emotional indicators, customer satisfaction, and customer loyalty. Hypotheses discussed in the framework of the conceptual model with the approach of path analysis are displayed in Fig. 3 where A, B, C, D, E and F in this figure represent emotional stimulants, social stimulants, price, emotional-cognitive indicators, satisfaction and loyalty, respectively. The standardized model of research along with the coefficients of each relationship can be seen in this figure. Now, the significance values of the relationships between variables should be considered in order to realize how much reliable the obtained coefficients are and to test the research hypotheses (these values are provided in Fig. 3).

Table 3

Hypotheses

\begin{tabular}{clccc}
\hline Hypotheses & Path & Standard estimation & t-value & Result \\
\hline 1 & $\begin{array}{l}\text { Emotional stimulants of the store atmosphere affect the social- } \\
\text { emotional indicators of the customer in point of purchase }\end{array}$ & 17.53 & Rejected \\
2 & $\begin{array}{l}\text { Social stimulants of the store atmosphere affect the social- } \\
\text { emotional indicators of the customer in point of purchase }\end{array}$ & 18.24 & 5.82 & Supported \\
\hline 3 & $\begin{array}{l}\text { The appropriate price of goods affects the emotional-perceptual } \\
\text { indicators of the customer. }\end{array}$ & 0.29 & 3.56 & Supported \\
4 & $\begin{array}{l}\text { Emotional-perceptual indicators of the customer affect his/her } \\
\text { purchasing satisfaction }\end{array}$ & 0.63 & 4.29 & Supported \\
5 & Customer satisfaction affects his/her loyalty & 0.11 & 2.18 & Supported \\
\hline
\end{tabular}

Note that if the significance value becomes greater than 1.96 the significance of the relationship between each two variables is confirmed. According to Table 3, the first hypothesis was rejected and the other four hypotheses were supported. The reasoning for this result is that the social stimulants of store atmosphere affect the social-emotional indicators of the customer in point of purchase. Furthermore, the appropriate of the store products affects the emotional-perceptual indicators of the customer, which result in the customer satisfaction and finally result in his/her loyalty and repurchase. However, in this research the relationship between emotional stimulants and emotionalperceptual indicators was not confirmed.

\subsubsection{Model fit indices}

In addition to estimate the model coefficients and errors, Lizrel software reports the indices by them the overall fitness of the model could be evaluated. Hier et al. (1998) emphasized three main criteria for the model fitness including the chi-square probability ratio (Chi-Square/df), goodness of fit index (GFI) and root mean square error approximation (RMSEA). Table 4 shows that most of the indices are greater than critical value and so, the research model is highly fitted to data in terms of fit indices.

\section{Table 4}

Model fit indices

\begin{tabular}{llllllll}
\hline Goodness & \multicolumn{1}{c}{$x^{2} / d f$} & GFI & RMSEA & RMR & NFI & NNFI & CFI \\
\hline Desired value & $<3.00$ & $>0.85$ & $<0.08$ & $<0.05$ & $>0.90$ & $>0.90$ & $>0.90$ \\
Results & 3.11 & 0.98 & 0.14 & 0.043 & 0.91 & 0.91 & 0.93 \\
\hline
\end{tabular}

\section{Discussion and conclusion}

After explaining the variables such as emotional stimulants, social stimulants, emotional-perceptual indicators, price, customer satisfaction, and customer loyalty, this study came to investigate the effect of emotional and social stimulants and prices of products on the emotional-perceptual indicators as well as the relationship between the emotional-perceptual indicators and customer satisfaction and finally, the relationship between customer satisfaction and loyalty. To reach this purpose, the relative literature was investigated and finally the conceptual framework of research was determined. Then, 
the research hypotheses were tested which had been constructed based on the relationships within the model variables. In order to test the hypotheses, data was analyzed using the different statistical methods and results were as following:

\subsection{Results relating to analysis of the relationships between model variables}

The relationship between emotional stimulants of the store atmosphere and emotional-perceptual indicators was measured in the first hypothesis and was not confirmed which was inconsistent with the study of Baker (1986), Bitner (1992), Berman and Evans (2009), and Turley and Miliman (2000). It was determined in the second hypothesis that the social stimulants of the store atmosphere affected the emotional-perceptual indicators of customer in point of purchase. Obtained results are similar with the study of Baker (1986), Bitner (1992), Berman and Evans (2009), and Turley and Miliman (2000). On the other hand, after investigating the third hypothesis it was determined that the store prices affected the emotional-perceptual indicators of customer in point of purchase. Obtained results are similar with the study of Shirai (2009), Mano and Oliver (1993), Richins (1997), and Westbrook and Oliver (1991). In the fourth hypothesis, the effect of emotional-perceptual indicators on the customer satisfaction was confirmed which was consistent with the study of Oliver (1981), Laros and Steenkamp (2004), Russell and Barrett Feldman (1999), Waston and Clarck (1992), Wirtz et al. (2000), Ladhari (2007), and Faullant et al. (2011). Finally in the fifth hypothesis, the relationship between the customer satisfaction and customer loyalty was investigated and confirmed which is consistent the study of Eggert and Ulaga (2002) and Cronin et al. (2000).

\subsection{Practical implications}

Retailing activity is such an activity that creates a deep and undeniable relationship between the store personnel. In line with this activity, the store personnel play an effective role in providing services for customers and making them loyal. In addition, their knowledge and awareness is needed for reaching to goals of the store and considered as one of the critical factors of retailing industry. Furthermore, the store managers are recommended to play relaxing music in the store environment, consider the shelves arrangement and illumination inside and outside the store carefully, train their employees to deal with customers and co-workers appropriately, and hire good-tempered and affable employees with tidy appearance. The managers should provide the facilities in order to speedy contact with customers and convey their opinions and complaints to management. Finally, all the store products should be price-tagged and sufficient information of their advantages and disadvantages should be provided to buyers.

\section{References}

Areni, C. S., \& Kim, D. (1993). The influence of background music on shopping behavior: classical versus top-forty music in a wine store. Advances in consumer research, 20(1), 336-340.

Babin, B. J., \& Attaway, J. S. (2000). Atmospheric affect as a tool for creating value and gaining share of customer. Journal of Business Research, 49(2), 91-99.

Baker, J. (1986). The role of the environment in marketing services: the consumer perspective. The services challenge: Integrating for competitive advantage, 79-84.

Baker, J., Parasuraman, A., Grewal, D., \& Voss, G. B. (2002). The influence of multiple store environment cues on perceived merchandise value and patronage intentions. The Journal of Marketing, 120-141.

Belk, R. W. (1975). Situational variables and consumer behavior. Journal of Consumer research, 157-164.

Barry, B. (2003). Retail management: a strategic approach. Pearson Education India.

Bitner, M. J. (1992). Servicescapes: the impact of physical surroundings on customers and employees. The Journal of Marketing, 57-71.

Chen, H. S., \& Hsieh, T. (2011). The effect of atmosphere on customer perceptions and customer behavior responses in chain store supermarkets. African Journal of Business Management, 5(24), 54-66.

Cronin Jr, J. J., Brady, M. K., \& Hult, G. T. M. (2000). Assessing the effects of quality, value, and customer satisfaction on consumer behavioral intentions in service environments. Journal of retailing, 76(2), 193218. 
Eggert, A., \& Ulaga, W. (2002). Customer perceived value: a substitute for satisfaction in business markets?. Journal of Business \& industrial marketing,17(2/3), 107-118.

Faullant, R., Matzler, K., \& Mooradian, T. A. (2011). Personality, basic emotions, and satisfaction: Primary emotions in the mountaineering experience. Tourism Management, 32(6), 1423-1430.

Holbrook, M.B. (1996). Consumer value: a framework for analysis and research. Advanced Consumer Resources, 23(1), 138-142.

Hul, M. K., Dube, L., \& Chebat, J. C. (1997). The impact of music on consumers' reactions to waiting for services. Journal of Retailing, 73(1), 87-104.

Imani, M. (2010). Investigating the factors that influence on experience and satisfaction in retail store industry, Tarbiyat Modares university.

Kaltcheva, V. D., \& Weitz, B. A. (2006). When should a retailer create an exciting store environment?. Journal of Marketing, 70(1), 107-118.

Kalwani, M. U., Yim, C. K., Rinne, H. J., \& Sugita, Y. (1990). A price expectations model of customer brand choice. Journal of Marketing research, 251-262.

Krishnamurthi, L., Mazumdar, T., \& Raj, S. P. (1992). Asymmetric response to price in consumer brand choice and purchase quantity decisions. Journal of Consumer Research, 387-400.

Ladhari, R. (2007). The effect of consumption emotions on satisfaction and word-of-mouth communications. Psychology \& Marketing, 24(12), 1085-1108.

Lai, F., Griffin, M., \& Babin, B. J. (2009). How quality, value, image, and satisfaction create loyalty at a Chinese telecom. Journal of Business Research, 62(10), 980-986.

Laros, F. J., \& Steenkamp, J. B. E. (2005). Emotions in consumer behavior: a hierarchical approach. Journal of business Research, 58(10), 1437-1445.

Lattin, J. M., \& Bucklin, R. E. (1989). Reference effects of price and promotion on brand choice behavior. Journal of Marketing research, 299-310.

Mano, H., \& Oliver, R. L. (1993). Assessing the dimensionality and structure of the consumption experience: evaluation, feeling, and satisfaction. Journal of Consumer research, 451-466.

Mehrabian, A., \& Russell, J. A. (1974). An approach to environmental psychology (Vol. 11). Cambridge, MA: MIT press.

Milliman, R. E. (1982). Using background music to affect the behavior of supermarket shoppers. The Journal of Marketing, 46, 86-91.

Rajendran, K. N., \& Tellis, G. (1994). Contextual and temporal components of reference price. Journal of Marketing, 58, 22-34.

Richins, M. L. (1997). Measuring emotions in the consumption experience.Journal of consumer research, 24(2), 127-146.

Ritzer, G. (2004). Enchanting a disenchanted world: Revolutionizing the means of consumption. Sage Publications, Incorporated.

Russell, J. A., \& Barrett, L. F. (1999). Core affect, prototypical emotional episodes, and other things called emotion: Dissecting the elephant. Journal of personality and social psychology, 76(5), 805-819.

Sherman, E., Mathur, A., \& Smith, R. B. (1997). Store environment and consumer purchase behavior: mediating role of consumer emotions. Psychology \& Marketing, 14(4), 361-378.

Shirai, M. (2009). Investigation of emotional responses to an unexpected price.Australasian Marketing Journal (AMJ), 17(1), 2-8.

Spangenberg, E. R., Crowley, A. E., \& Henderson, P. W. (1996). Improving the store environment: do olfactory cues affect evaluations and behaviors?. The Journal of Marketing, 60(2), 67-80.

Swinyard, W. R. (1993). The effects of mood, involvement, and quality of store experience on shopping intentions. Journal of Consumer Research, 20(2), 271-280.

Turley, L. W., \& Milliman, R. E. (2000). Atmospheric effects on shopping behavior: a review of the experimental evidence. Journal of Business Research,49(2), 193-211.

Watson, D., \& Clark, L. A. (1992). Affects separable and inseparable: on the hierarchical arrangement of the negative affects. Journal of Personality and Social Psychology, 62(3), 489-505.

Westbrook, R. A., \& Oliver, R. L. (1991). The dimensionality of consumption emotion patterns and consumer satisfaction. Journal of consumer research, 84-91.

Wirtz, J., Mattila, A. S., \& Tan, R. L. (2000). The moderating role of target-arousal on the impact of affect on satisfaction —an examination in the context of service experiences. Journal of Retailing, 76(3), 347-365. 